\title{
HUMOR E CRÍTICA SOCIAL NA ARTE DE HOGARTH NA INGLATERRA SETECENTISTA
}

Laila Luna de León ${ }^{1}$

\begin{abstract}
Resumo: O presente artigo tem como objetivo refletir sobre a sátira política na Inglaterra do século XVIII, em particular sobre as obras do pintor e gravador William Hogarth. O artista proveniente das classes médias e contrário a uma arte acadêmica e elitista produziu uma vasta obra de sátiras, que tinham como objetivo comentar e instigar a reflexão sobre a sociedade moderna dentro de uma proposta ilustrada reformista e pedagógica. Uma de suas principais características era o uso do humor, considerado um gênero vulgar, com elementos clássicos para tecer suas observações sobre o mundo moderno. As imagens produzidas por Hogarth são uma fonte riquíssima sobre as visões de mundo e valores próprios da modernidade, e, portanto, buscaremos através de algumas de suas sátiras políticas selecionadas, pensar suas estratégias de usar o humor para ensinar lições morais e tecer duras críticas aos governantes e as classes mais ricas.
\end{abstract}

Palavras-chave: Inglaterra; Século XVIII; Ilustração; William Hogarth; Sátiras.

\section{HUMOR AND SOCIAL CRITICISM IN HOGARTH'S ART IN EIGHTEENTH CENTURY ENGLAND}

\begin{abstract}
This present article has the goal to reflect about political satire at eighteenth century England, in particular the works of the painter and engraver William Hogarth. The middle classes's artist, against an academic and elitist art produced a vast work of satires that had the goal to coment and intisgate the reflection about modern society within a enlightened, reformist and pedagogical proposal. One of the main feature was the use of humor, considered a vulgar genre, with classical elements, to make his observations about the modern world. The images produced by Hogarth are a rich source about world's vision and modern values, and therefore, we'll seek trough some of his satires, to think his estrategies of using humour to tech moral lessons and to make harsh critics to the rulers and richer classes.
\end{abstract}

Keywords: England; Eighteenth Century; Enlightenment; William Hogarth; Satires.

\section{HUMOR Y CRÍTICA SOCIAL EN EL ARTE DE HOGARTH EN LA INGLATERRA SETECENTISTA}

Resumen: El presente artículo tiene como objetivo reflexionar sobre la sátira política en la Inglaterra del siglo XVIII, en particular sobre las obras del pintor y grabador William Hogarth. El artista proveniente de las clases medias y contrario a un arte académico y elitista produjo una vasta obra de sátiras, que tenían como objetivo comentar e instigar la reflexión sobre la sociedad moderna dentro de una propuesta ilustrada reformista y pedagógica. Una de sus principales características era el uso del humor, considerado un género vulgar, con elementos clásicos para tejer sus observaciones sobre el mundo moderno. Las imágenes producidas por Hogarth son una fuente riquísima sobre las visiones de mundo y valores

\footnotetext{
${ }^{1}$ Doutoranda em História pela Universidade Federal Fluminense (UFF).
} 
propios de la modernidad, y por lo tanto buscaremos a través de algunas de sus sátiras políticas seleccionadas, pensar sus estrategias de usar el humor para enseñar lecciones morales y tejer duras críticas a los gobernantes y las clases más ricas.

Palabras clave: Inglaterra; Siglo XVIII; Ilustración; William Hogarth; Sátiras.

\section{INTRODUÇÃO}

O começo do século XVIII foi um período muito rico na produção de sátiras políticas na Inglaterra, especialmente no teatro, na literatura e nas gravuras. A conjuntura pósRevolução Gloriosa (1688/89) proporcionou o ambiente ideal para a proliferação da sátira política, pois, se por um lado o Ato de Tolerância de 1689 e o fim do Ato de Licenciamento em 1695 ajudaram a impulsionar o boom da produção da imprensa no século seguinte, por outro lado, a instabilidade política por conta das rivalidades entre os partidos Tory e Whig, e os escândalos de corrupção proporcionaram um vasto material para os satiristas. Historiadores britânicos como Roy Porter (2000) e Peter Burke (2010) se destacaram em debates sobre assuntos políticos e se tornaram parte da rotina na cidade de Londres, através de diversos periódicos, jornais e revistas, e também em centros de conversação e sociabilidade como as coffee-houses que proliferaram na cidade inglesa nesse período.

Roy Porter (2000) defende a tese de que as Luzes ocorreram na Inglaterra, especialmente na primeira metade do século XVIII, fora dos ambientes institucionais e das discussões epistemológicas, não como um combate ao sistema vigente, como foi na França, mas como uma linguagem concomitante às mudanças, fundamentada na ideia de emancipação das amarras do passado, e possibilidade de conceber um novo futuro. E foi na cultura impressa que essa linguagem se desenvolveu com mais força, fundada na valorização da modernidade e de uma abordagem racionalizada da moral pautada pela difusão do conhecimento, o que incluía a apreciação dos prazeres da imaginação (ou seja, das artes e do pensamento), como meio mais eficiente para a ordenação social.

Jornais e periódicos proliferaram não apenas na região metropolitana, mas também nas províncias. Havia jornais diários, semanais e dominicais. Eles também potencializaram o debate político assumindo uma postura clara como The Observator, de 1702, partidário Whig, ou The Rehearsal, de 1704, e The Review, publicado entre 1704 e 1713 por Daniel Defoe, ambos da oposição Tory. Peter Burke (2010) destaca que o debate não excluía as classes populares, uma vez que era comum a prática de juntarem ao redor de alguém que saiba ler 
para ouvir os artigos desses jornais, que em geral custavam dois pence. Mas eles não se limitavam ao debate político e muitos discutiram moral, moda, costumes e crítica artística como The Spectator e The Tatler, editado por Joseph Addison e Richard Steele no início do século XVIII, e mais tarde na década de 1730, Gentleman's Magazine. Addison pode ser considerado um dos principais nomes na formulação de um ideal de polidez através da educação e das artes. Ele buscou divulgar em seus periódicos a filosofia, pois acreditava que esta não deveria ficar confinada aos meios acadêmicos pomposos e sim provocar a discussão de novas ideias:

Eu considero uma alma humana sem educação como mármore na pedreira, que não mostra nenhuma da sua beleza inerente, até que o talento do polidor traz a tona suas cores, faz a superfície brilhar e descobre cada mancha, borrão e nervura ornamentais que correm pelo seu corpo. Educação, da mesma maneira, quando trabalha na mente nobre, traz à vista cada virtude $\mathrm{e}$ perfeição latentes, que sem tal ajuda jamais seriam capazes de se tornarem aparentes (ADDISON, J. The Spectator, 1711, no 215).

William Hogarth (1697-1764) surgiu nesse cenário como um artista singular, nascido numa família modesta, filho de um professor de Latim e escritor, com uma proposta de arte que desafiava os padrões da arte pomposa e aristocrática do começo do século XVIII. A arte de Hogarth expressa não apenas novas formas de ver o mundo a partir de valores da modernidade, mas um propósito reformista bastante racional e pragmático. Buscando um lugar entre o "grotesco e o sublime", entre o vulgar e o clássico, Hogarth representou o cotidiano londrino numa perspectiva que era ao mesmo tempo cômica e moralizante, e que pode ser entendida como uma "pedagogia do entretenimento", pois, em suas próprias palavras, seu principal objetivo era: "entreter e aperfeiçoar as mentes".

O presente artigo pretende assim refletir sobre como Hogarth utilizou a sátira e o humor como uma estratégia não apenas para atrair um crescente mercado interessado no consumo da cultura, mas também com um propósito ilustrado de ensinar através da arte para um público composto não por cavalheiros, mas por "indivíduos comuns". Nessa perspectiva destacamos duas fases distintas do artista em que o humor e a crítica política convergiram com sua arte moralizante e expuseram ao ridículo a corrupção dos governantes, que deveriam ser aqueles a prestar exemplos de boa conduta, ética e honestidade. De modo geral, Hogarth esteve ao longo de sua trajetória mais preocupado em retratar e satirizar a sociedade e seus indivíduos a partir de suas escolhas e de suas hipocrisias, sem poupar nenhuma classe social, mas temas como a assimetria da justiça (com punições diferentes para os ricos e para os 
pobres) e a hipocrisia daqueles em posição de julgar e condenar os outros foram constantes em sua obra, mesmo que de modo sutil.

\section{INSTABILIDADE, CORRUPÇÃO E A SÁTIRA SETECENTISTA}

As primeiras décadas do século XVIII na Inglaterra foram marcadas pela instabilidade política e pelas disputas como destaca o historiador Jeremy Black: "A instabilidade dos ministérios no período de 1689-1722 sugere que o ambiente político para uma monarquia parlamentar efetiva foi de certo modo obstruído pelos eventos de 1688-89" (BLACK, 2005:7). De acordo com o historiador, para que uma monarquia parlamentar funcionasse era preciso o desenvolvimento de padrões e convenções políticas que permitissem a coexistência entre diferentes opiniões políticas, e isso levava tempo, e as guerras com a França (Guerra dos Nove Anos, 1688-1697 e Guerra de Sucessão Espanhola 1702-1713) não ajudaram. Para Black (2005), a ressonância cultural da Revolução Gloriosa precedeu sua estabilidade politica nesse sentido.

Em 1689, a ascensão do Rei William III, príncipe de Orange, casado com a Rainha Mary II, da casa dos Stuarts, garantiu a implementação de uma monarquia parlamentar. A Bill of Rights rompia com a sucessão dinástica hereditária e a substituía pela "vontade da nação expressa pelo Parlamento", e, como destaca Paul Langford (1984, p. 4), num período de ascensão e fortalecimento do Absolutismo no mundo ocidental era definitivamente uma rejeição simbólica de toda uma concepção de governo. No entanto, a questão da legitimidade dinástica era ainda uma barreira cultural a ser ultrapassada, e como destacou Black, as novas instituições ainda não tinham amadurecido suficientemente para garantir a estabilidade política: “a remoção de James II por William III em 1688-89 foi um avanço para visões particulares da Inglaterra, Escócia e Irlanda, mas não assegurou a dominância dessas visões de modo instantâneo." (BLACK, 2001, p. 5).

O que sucedeu à Revolução Gloriosa foi uma maior ansiedade sobre o futuro do regime, uma vez que não era garantido pelo direito hereditário, que se estenderia até a definitiva derrota dos Jacobitas, em 1746. O Partido Tory ainda o considerava William III um usurpador e se aproximou dos Jacobitas, que reivindicavam o retorno do rei deposto James II e acabou marginalizado do poder, mas após suas vitórias militares, ele conquistou a prerrogativa patriótica de considerar seus oponentes desleais. O Partido Whig funcionou como principal suporte político de William III e seu discurso militarista, apoiado pelas sucessivas 
vitórias na Guerra dos Nove Anos contra a França e, na sequência, sua participação bem sucedida na Guerra da Sucessão Espanhola, assim como para uma política interna adotada que incluía o fim da censura pré-publicação (1695) e a fundação do Banco da Inglaterra (1694) (BLACK, 2001, p. 5).

A transição para a dinastia Hanover com o rei germânico George I em 1714 também não seria suficiente para apaziguar os ânimos e neutralizar a oposição, com o início da rebelião Jacobita, em 1715, que reivindicava o direito de James III, filho de James II como legítimo monarca inglês. Além disso, a posição de George I em favorecer o Partido Whig, estabelecendo mecanismos de dominação destes nos principais altos cargos do governo causaria um grande impasse político, estreitando os laços do Partido Tory com os Jacobitas e a sua reivindicação de reestabelecer a dinastia Stuart.

Apesar de vitorioso em sufocar a Rebelião Jacobita, George I teve que lidar com uma forte onda de acusações de corrupção implicando os principais nomes de seu governo. Nesse sentido, talvez nenhum escândalo político nesse período tenha sido tão marcante como o caso da Bolha de South Sea, na primavera de 1720, um escândalo financeiro da South Sea Company, fundada em 1711 pelos ministros tories da Rainha Anne como uma alternativa ao Banco da Inglaterra, controlado pelos whigs. Em 1719, já sob George I e a oligarquia whig foi montado um esquema para redistribuir a Dívida Nacional em melhores termos. A grande dificuldade de sua administração era o número de interesses que envolvia, e precisava garantir os lucros para toda sua base de apoio político como cortesãos e ministros, interessados em lucro rápido. Por conta do rápido crescimento das ações, a especulação foi generalizada, garantida por um regime corrupto e investidores ingênuos, crescendo uma "bolha" que rapidamente inflacionou os preços. As consequências, de acordo com Paul Langford (1984, p. 16-18) foram devastadoras, especialmente para aqueles que venderam seus bens para comprar ações.

O caso de South Sea precedeu uma série de investigações parlamentares sobre extensiva corrupção em altos cargos na década de 1720, como as acusações dos diretores e oficiais da Corporação de Caridade - cujo trabalho era prover emprego e assistência aos pobres- de especulação, apropriação indevida e especulação direta, e o impeachmemt do Lord Chancellor, Lord Macclesfield, por organizar a venda cargos judiciais: “a Bolha de South Sea é melhor vista não com o grand finale da Inglaterra pós-Revolução, mas como um espetacular 'abrir de cortinas' para a prosperidade, vulgaridade e comercialismo de meados do século XVIII" (LANGFORD, 1984, p. 19). O comportamento corrupto e imoral nos mais altos 
cargos do governo, incluindo as sérias suspeitas contra o primeiro ministro Robert Walpole, que atuou no cargo entre 1721 e 1742, inferiam a tese de que a decadência moral se expandia pela sociedade como consequência, com aumento da criminalidade, dos vícios e da luxúria, e um dos principais meios de expressão dessas insatisfações foi através da sátira social e política que se expandiu consideravelmente nas décadas de 1720 e 1730 no teatro, na literatura e na cultura visual.

O teatro foi um dos principais espaços onde a questão política refletiria quase que diretamente na sua estrutura, fossem trabalhos individuais ou nas respostas a esses: "o caráter partidário da cultura pode ser facilmente visto no conteúdo e performance das peças" (BLACK, 2005, p. 8). As peças de teatro funcionavam como panfletos políticos e a reação da audiência era uma oportunidade de estabelecer alianças e demarcar oposições. Esse foi o caso da tragédia Cato (1713), do renomado editor do periódico The Spectator, Joseph Addison, partidário Whig, uma obra carregada em propaganda política que era aclamada ou criticada em acordo com a filiação partidária do espectador. A ópera-balada Beggar's Opera (1727) de John Gay apresentava como protagonista o contrabandista Macheath e fazia paralelos entre o mundo do crime e o governo de Walpole. O uso do palco pela oposição ao governo era uma grande preocupação, especialmente durante o ministério de Robert Walpole, com a recusa de licença para performance de John Gay e sua peça satírica Polly, de 1729.

A sátira setecentista, de acordo com Ronald Paulson (1967), se desenvolveria na Inglaterra como um novo gênero, ainda que com fortes raízes naquele desenvolvido por Swift e Pope, com maior interesse na experiência humana com um estrito julgamento moral. As mudanças políticas, econômicas e sociais pós- Revolução Gloriosa afetaram também a esfera cultural profundamente e novas questões passaram a ser pautadas como relevantes para uma abordagem da sociedade moderna, como explica Paulson no caso da literatura e do surgimento do romance moderno: "A nova era requeria uma nova forma literária que expressasse uma interpretação das ações dos homens mais justa e mais "histórica", uma que considerasse motivos e circunstâncias atenuantes antes de realizar julgamento" (PAULSON, 1967, p.3).

A sátira em geral, como sugere Paulson (1967), julgava o homem não pelo que ele é, mas pelo que ele fez, e acabava por reduzi-lo à ação. A sátira na época da Ilustração transitou, desse modo, da preocupação com as ações do personagens e as consequências morais dessas ações para uma preocupação com as respostas à consciência do personagem. O autor sublinha que os principais artistas da primeira metade do século XVIII eram satiristas ou ao menos 
praticavam a sátira de algum modo. Uma vez que para esses artistas, o humanismo cívico estava infectado com corrupção e artificialidade, e era através do uso da sátira que poderiam expressar um discurso moral sobre caráter e conduta. Vale destacar, no entanto, que por mais popular que a sátira fosse, ela se opunha a respeitabilidade dos gêneros prevalecentes do ideal polido e refinado:

Os gêneros que eles desenvolveram, da sátira ao romance, estavam combatendo o que era considerado como gosto, literatura e pintura na Era de Walpole. Mas é claro que a sátira estava aspirando ao cânone desafiando-o, por exemplo, ao criticar o épico, ao invés de melhorá-lo (...). (PAULSON, 1967, p. 7).

$\mathrm{Na}$ forma literária, a principal expressão dessa mudança foi através do romance moderno, que combinava uma abordagem realista da sociedade moderna com o julgamento moral, tendo como principais nomes Daniel Defoe, Samuel Richardson e Henry Fielding. "Tudo é copiado do livro da natureza, e é raro uma personagem ou ação que eu não tenha tomado da minha própria observação e experiência" (FIELDING, 1947), afirmou Fielding no prefácio de Joseph Andrews em 1742. Na cultura visual, a sátira encontrava-se presente mais nas gravuras de circulação em massa do que nas artes visuais consideradas refinadas. Enquanto os pintores de renome se dedicavam ao idealismo neoclássico, com ninfas, querubins e uma releitura da virtude moral do humanismo cívico, o mercado de gravuras se dividia entre as cópias das obras clássicas dos Grandes Mestres e as gravuras satíricas que abordavam temas recorrentes do cenário político e social da Inglaterra setecentista, um cenário particularmente rico em inspirações para os gravadores.

\section{HOGARTH E A REPRESENTAÇÃO DO CAOS}

William Hogarth iniciou sua trajetória como artista na produção de gravuras satíricas sobre o conturbado período político inglês na década de 1720. A sátira era uma linguagem que permitia a Hogarth criticar o gosto polido e refinado dentro dos termos estabelecidos naquele período, e conquistar um mercado consumidor em pleno crescimento. O humor era assim um elemento fundamental na sua produção visual, pois lhe proporcionava uma maior liberdade em provocar personagens proeminentes da política inglesa de forma indireta, sem comprometer seus próprios interesses de cultivar uma patronagem entre a aristocracia e a gentry. Além disso, as gravuras satíricas atingiam um público que se tornaria a base da trajetória do artista: era o mercado anônimo que estava em pleno crescimento no século XVIII 
composto por indivíduos das classes médias ${ }^{2}$ interessados em consumir arte, mas que não podiam exercer a patronagem individual.

As primeiras gravuras originais de Hogarth abordariam exatamente temas polêmicos e populares, relativos a esse período conturbado de transições políticas. Como a biógrafa do artista, a historiadora Jenny Uglow (1997) destaca, as críticas ao regime de Walpole eram uma escolha delicada com a qual o artista tinha que lidar, especialmente pelo fato de seu mestre e futuramente sogro, o pintor James Thornhill ser um ativo partidário whig:

Ele tinha que equilibrar lealdades, e na política era difícil para o artista saber em qual cavalo cavalgar. Se ele estivesse procurando por patronos, então Thornhill tinha conexões com Walpole e a Corte - porém o público queria gravuras anti-Walpole, e em meados de 1720 uma poderosa oposição estava emergindo, que também poderia prover patronos (UGLOW, 1997, p. 116).

A biógrafa de Hogarth entende que apesar de suas relações com Thornhill, e sua profunda admiração pelo mestre, o artista ansiava por patronos na oposição ao Rei George I e à hegemonia Whig. Isso não significava que seu posicionamento político se aproximasse das ideias conservadoras dos tories ou dos jacobitas, mas indicava o início de uma busca pela liberdade artística que marcou sua trajetória. A sátira em Hogarth começou a partir de temáticas comuns a outros gravadores, incluindo as críticas ao governo e ao comportamento imoral e corrupto de seus governantes, em particular ao ministro Walpole.

Suas primeiras gravuras produzidas em 1721 e publicadas juntas em 1724, South Sea Scheme (fig.1) e The Lottery (fig.2), abordavam questões político-econômicas particulares do regime implementado na Inglaterra e paralelamente satirizavam as dinâmicas sociais da modernidade de modo mais geral. O caso da Bolha de South Sea abriu a década de 1720 como a principal polêmica, e como era de se esperar, foi amplamente satirizado pelos gravadores da época, afinal, era um assunto de grande interesse do público que oferecia uma oportunidade valiosa em ridicularizar os poderosos, apontar suas hipocrisias e criticar o cenário de corrupção política que marcou as primeiras décadas do século XVIII.

De acordo com Ronald Paulson (1991, p. 67), um grande fluxo de gravuras satíricas provenientes de Amsterdã inspirou artistas ingleses a primeiro copiar e depois produzir suas

\footnotetext{
${ }^{2} \mathrm{O}$ termo classes médias foi adotado para designar os grupos sociais considerados intermediários, que se situavam entre as classes da aristocracia e gentry e as classes populares. Ainda que não tenha existido uma consciência de classe até o século XIX e o termo possa soar anacrônico, ele se apresenta como a melhor opção para designar as complexas estruturas da sociedade inglesa do século XVIII, sendo utilizado pela maior parte dos historiadores britânicos para definir o heterogêneo grupo social também conhecido como "middle station", "middle rank" ou "middling sort of people" que incluía ricos mercadores, comerciantes, profissionais liberais, entre outros.
} 
próprias versões, firmando assim uma tradição da sátira gráfica. A gravura (fig.1) produzida por Hogarth poderia perder-se no meio de tantas outras abordagens do assunto, mas já chamava a atenção por uma das características mais marcantes do artista: a capacidade em tratar de um tema específico ao mesmo tempo em que comentava de modo sútil e ácido sobre as dinâmicas sociais. Hogarth se voltava para a corrupção moral nas ruas londrinas. Os versos inscritos na gravura anunciavam como o escândalo havia corrompido a sociedade: "Aqui as causas porque em Londres, tantos homens são feitos e desfeitos”.

Figura 1 - South Sea Scheme, William Hogarth

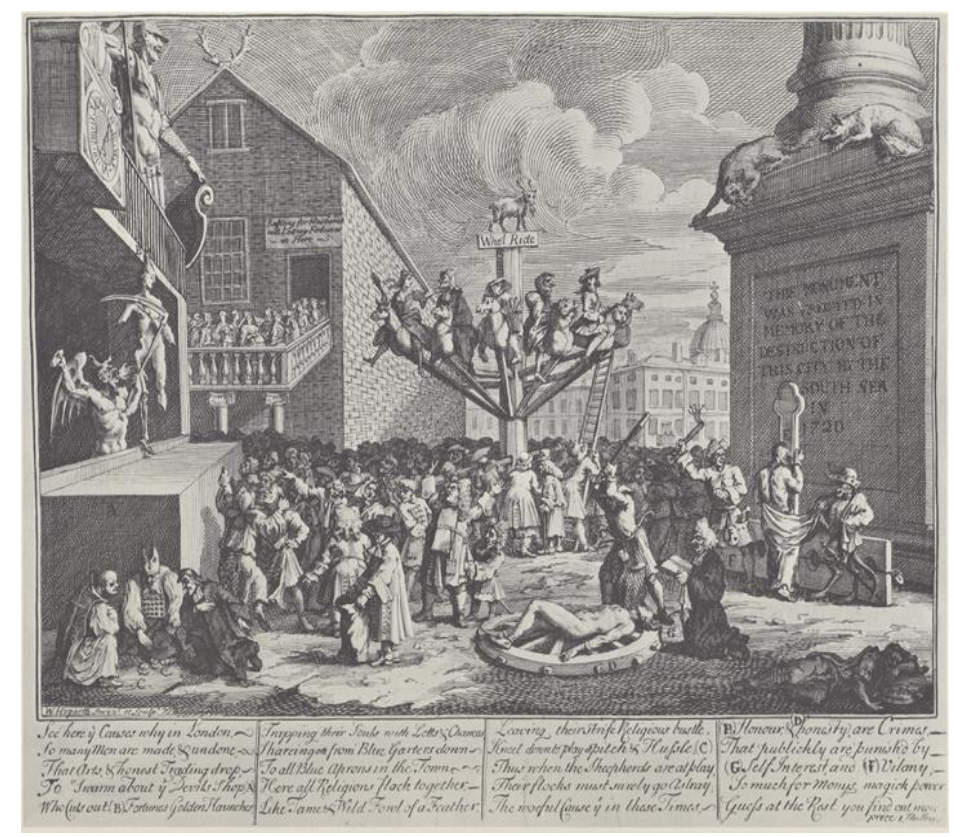

Fonte: British Museum, 1721.

A roda da fortuna de Hogarth ao centro da gravura assemelha-se a um carrossel com personagens que representam diversos papéis sociais como um clérigo, uma prostituta, uma senhora e um nobre. A roda da fortuna era considerada um lugar-comum das gravuras políticas, e, de acordo com o historiador da arte E. H. Gombrich (1999) foi criada por Boécio na Antiguidade para simbolizar os altos e baixos do destino Ao utilizar essa alegoria comum na cultura visual, Hogarth buscava enunciar de modo bastante direto a efemeridade de uma vida baseada na ambição financeira. O artista também recorreu a alegorias clássicas para representar as virtudes sendo maltratadas e punidas pelos vícios: a Honestidade é torturada pelo Interesse Próprio, a Honra pela Vilania e alvo da zombaria de um macaco vestido de 
cavalheiro $^{3}$, e o Diabo arranca a pele da Fortuna vendada. Na legenda das gravuras, era detalhada cada alegoria, com a indicação de sua posição na imagem, tornando a sua interpretação ainda mais acessível ao público.

O grupo de apostadores no canto inferior esquerdo da composição simbolizava a natureza da especulação financeira como um jogo de azar, e foram representados por Hogarth como representantes das três religiões dominantes no Ocidente: um judeu, um padre católico e um puritano jogam cartas e ignoram o caos ao seu redor, sugerindo que os religiosos tinham maior preocupação com seus próprios interesses do que com seu rebanho, e ironicamente ao fundo, o artista colocou a Igreja de St. Paul, símbolo da caridade cristã. O Monumento do Grande Incêndio de Londres de $1666^{4}$ é representado com a seguinte inscrição: "Esse monumento foi erguido em memória da destruição da cidade pelo South Sea em 1720", com essa perspectiva, o artista comparava o escândalo financeiro a um incidente de ordem natural e com consequências igualmente catastróficas. É interessante notar que ambos os "desastres" foram atribuídos no imaginário, à ambição e ao vício que infestavam Londres, tornando a comparação de Hogarth bastante coerente. No canto, o comércio, representado por uma mulher em trapos e miserável, é mais uma vítima de toda a corrupção e não a sua causa.

Com um propósito muito similar, The Lottery (fig.2) abordava a questão do crédito nacional, mas com uma abordagem clássica e alegórica, diferente do estilo holandês de reprodução do cotidiano, inspirado na Escola de Atenas e na "Disputa de Rafael". Segundo Paulson: "o emblemático holandês e o alegórico italiano foram os dois métodos que Hogarth tentou de várias maneiras juntar na década seguinte e se uniram juntando alusões bíblicas e clássicas (...)" (PAULSON, 1991, p. 73). Hogarth frequentou uma academia de arte na década de 1720, e como filho de professor de Latim possuía um certo conhecimento clássico, mas sempre rejeitou a superioridade de uma educação formal, especialmente para artistas, considerando a reverência ao passado extremamente danosa. Nessa perspectiva, os elementos clássicos eram utilizados a serviço do humor e as legendas explicativas permitiam que qualquer indivíduo pudesse compreender, mesmo sem qualquer tipo de educação formal. Em The Lottery (fig.2), a partir de uma pintura clássica de Rafael (“A Escola de Atenas”) e usando alegorias clássicas satirizou a ganância do governo e dos poderosos. Ao utilizar a obra

\footnotetext{
${ }^{3}$ A alegoria do macaco como cavalheiro é recorrente nas sátiras do século XVIII, e presente em mais de uma gravura de Hogarth, e se refere à imitação de algumas categorias sociais dos modos da aristocracia, de maneira exagerada que se torna ridícula. Em inglês o jogo de palavra fica mais evidente pois ape pode tanto significar símio quanto imitação.

${ }^{4}$ Em 1666 um Grande Incêndio destruiu parte de Londres e teve grande impacto no imaginário, como uma ação divina para punir pelos pecados.
} 
de um artista considerado "sublime" para fazer comédia, Hogarth demonstrava uma resistência de submissão aos Grandes Mestres da Renascença.

Figura 2 - The Lottery, William Hogarth

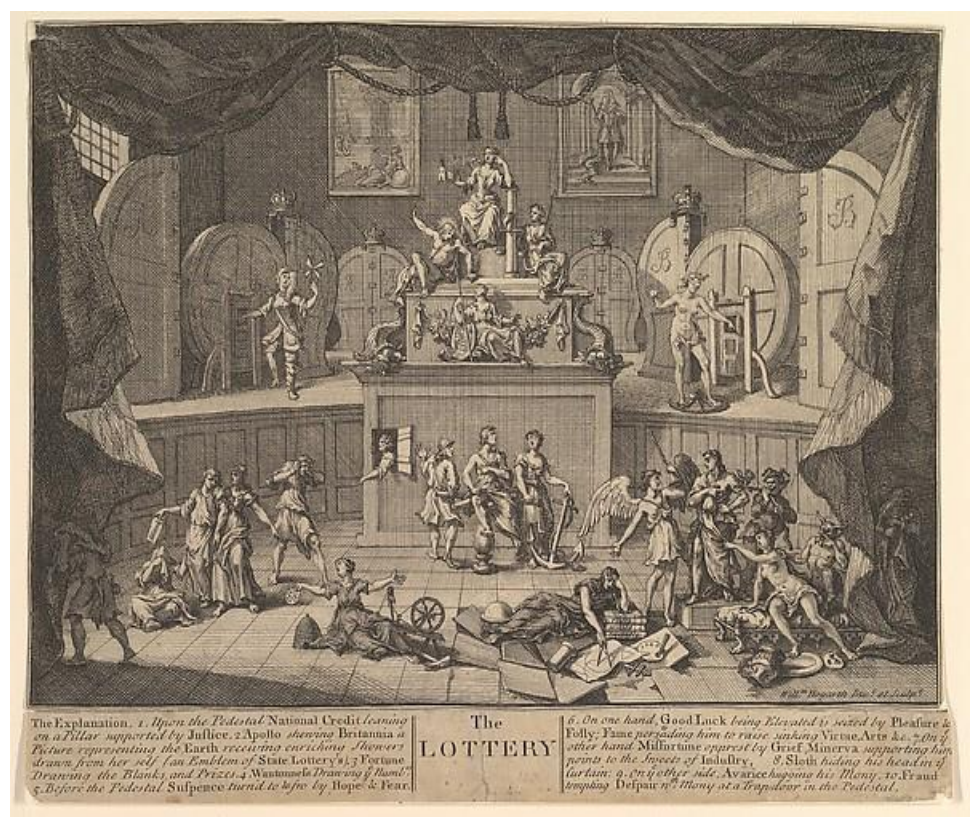

Fonte: Met Museum, 1724.

A Loteria, assim como a roda da fortuna, era outro lugar-comum da sátira gráfica: "por anos loterias tinham sido alvo de sátira, pois visavam tanto um estado construído na aposta de dinheiro quanto o desejo geral por dinheiro fácil, o sonho mágico de uma vida transformada" (UGLOW, 1997, p. 89). Quase todo gravador tinha uma gravura com essa temática, assim como no South Sea Bubble que Hogarth tomou um assunto já muito representado, o que resultava numa grande repetição de elementos e uma originalidade mais limitada: "o elenco alegórico divide o espaço com emblemas gastos - roda da fortuna, cata vento, castelos no ar" (UGLOW, 1997, p. 89).

Não deve causar espanto que as primeiras gravuras originais de Hogarth demonstrem um artista tentando definir seu estilo, que suas preferências e que suas escolhas ainda fossem pautadas por temas com grande apelo no mercado, de modo a firmar seu nome entre as prensas e o público consumidor. Temas polêmicos que estampavam os jornais e periódicos, especialmente aqueles com um apelo político eram uma aposta certeira para atrair publicadores e compradores e possivelmente com essa intenção. As sátiras de Hogarth na década de 1720 podem ter se perdido entre várias outras que abordavam os mesmos temas, e podem muitas vezes ser interpretadas como mais voltadas aos interesses do mercado 
consumidor, do que como um posicionamento político definido. Mas elas indicavam uma tendência na qual o artista buscaria pautar o conjunto de sua obra: o uso do humor para explicitar as hipocrisias e também como um caminho para desenvolver lições morais.

\section{HUMOR E CRÍTICA SOCIAL NO MODERNO OBJETO MORAL}

A sátira política não foi retirada das obras de Hogarth, mas a partir da década de 1730 deixava de ser seu ponto de partida e as temáticas morais passariam a nortear a sua obra, que se afastava das tendências pomposas e aristocráticas da pintura histórica neoclássica e buscava uma estética moral e realista. O moderno objeto moral desenvolvido pelo artista buscava dignificar a arte a partir de um gênero moderno, que valorizasse a observação da natureza e tivesse uma função pedagógica. Ele buscou assim um gênero "intermediário entre o sublime e o grotesco" (NICHOLS, 1833, p. 9). Ao utilizar o termo sublime, Hogarth se referia em especial à pintura histórica e seus conceitos, considerada a forma mais nobre de arte. Paulson (1996) explica que sublime era um termo utilizado para denominar "alta arte", e entendido como algo que transcendia o belo. $\mathrm{O}$ sublime pode ser contextualizado no século XVIII com a estética idealista, e implicava desse modo o aperfeiçoamento da natureza, a supressão das imperfeições.

O grotesco, por sua vez, era no século XVIII condenado pelos padrões de gosto pautados nos cânones clássicos. O idealismo e a transcendência do corporal se opunham ao realismo grotesco caracterizado, segundo Bakhtin, pelo "rebaixamento", ou seja, "a transferência ao plano material e corporal, o da terra e do corpo, na sua indissolúvel unidade" (BAKTHIN, 2010, p. 17). Os cânones clássicos instigaram uma interpretação do grotesco como monstruoso e disforme que destoava da "estética do belo" (BAKTHIN, 2010, p. 26). O termo grotesco possuía no século XVIII uma denotação de desprezo, associado à cultura popular de baixa qualidade e, como afirma Laura Nery, é possível crer que em Hogarth este significasse "a corrupção do gosto ou a ociosa aventura pelo mundo dos sonhos e da fábula" (NERY, 2006, p. 123). Assim, ao mesmo tempo em que buscava se afastar do estilo histórico, repleto de imagens etéreas e perfeitas, também rejeitava a incursão na monstruosidade e no sobrenatural, associado à irracionalidade. Por isso seu objeto era intermediário, pois se encontrava no mundo no qual vivia e admirava com suas belezas e imperfeições: 
Nessas composições, os temas que irão tanto entreter quanto aperfeiçoar as mentes, sendo da maior utilidade publica, e devem, portanto, ser dignos de figurar nas mais altas classes. Se a execução é difícil (ainda que seja um mérito secundário), o autor pode clamar por um elogio maior. Se isso for admitido, comédia, na pintura e na escrita, será relegada ao primeiro lugar como mais capaz dessas perfeições, ainda que o sublime como é chamado, tenha lhe sido oposto (NICHOLS, 1833, p. 9).

Desse modo, o moderno objeto moral não se opunha aos princípios de instrução pública da pintura histórica neoclássica, mas Hogarth não se absteve da possibilidade de também entreter o seu público, através da inserção da comédia. Para o artista essa combinação elevava seu gênero a um grau superior de inovação e dificuldade, justificando seu clamor para figurar no topo da hierarquia dos gêneros de arte. A comédia, considerada tanto na pintura como na literatura e no teatro como inferior, para Hogarth era exatamente o elemento que elevava a complexidade do seu objeto. A pedagogia do entretenimento de Hogarth transcendia o didatismo moralizante e conservador, pois possui elementos de subversão através da comédia. Como destaca Mikhail Bakhtin em seu estudo sobre Rabelais e a história do riso, o riso pode ser empregado de forma libertadora dentro do domínio de um gênero "sério":

O verdadeiro riso, ambivalente e universal, não recusa o sério, ele purifica-o e completa-o. Purifica-o do dogmatismo, do caráter unilateral, da esclerose, do fanatismo, e do espírito categórico, dos elementos de medo ou intimidação, do didatismo, da ingenuidade e das ilusões, de uma nefasta fixação sobre um plano único, do esgotamento estúpido. O riso impede que o sério se fixe e se isole da integridade inacabada da existência cotidiana. Ele reestabelece essa integridade ambivalente. Essas são as funções do riso na evolução histórica da cultura e da literatura (BAKTHIN, 2010, p. 105).

Ao combinar elementos cômicos às suas composições moralizantes, ele ultrapassou a rigidez de um discurso conservador e imprimiu uma visão mais ampla e menos dogmática das questões da sociedade moderna. Bakhtin (2010) afirma que a coexistência do sério e do cômico promovem uma interpretação integral do mundo, em oposição ao isolamento desses aspectos. As séries de Hogarth tratavam da observação do indivíduo e das suas relações sociais, e desse modo se debruçava sobre as questões da natureza humana. Assim, em suas imagens moralizantes, gravuras e telas, o moralismo conservador foi expurgado pela ridicularização da hipocrisia. É nesse sentido que "o riso expurga a consciência da seriedade mentirosa, do dogmatismo, de todas as afetações que a obscurecem (a verdade)" (BAKTHIN, 2010, p. 120).

Em dezembro de 1732, Hogarth anunciou as gravuras de Midnight Modern Conversation (fig.3) - também produzida como tela sob óleo -, onde representava 
"cavalheiros" numa situação imoral. No lugar do tradicional cenário de chá e jogos de cartas entre damas e cavalheiros polidos, um grupo de onze homens bêbados numa decadente taverna. Com inspiração nas pinturas holandesas de tavernas de artistas como Jan Steen, a imagem ainda mantinha um propósito moral de ridicularizar os excessos dos "homens de respeito" e apontar para suas hipocrisias. Ele manteve as identidades anônimas como explica o subtexto da gravura: "Think not to findo ne meant Reasemblance there/ We lash vices but the Persons spare" (Não espere encontrar qualquer semelhança aí/ Nós satirizamos vícios, mas poupamos as Pessoas), e como destaca o historiador da arte Vic Gatrell (2014), um dos seus atrativos era a diversão de tentar adivinhar os personagens da imagem e, por anos em Londres discutiu-se quem eram os homens retratados por Hogarth.

Figura 3 - Midnight Modern Conversation, William Hogarth

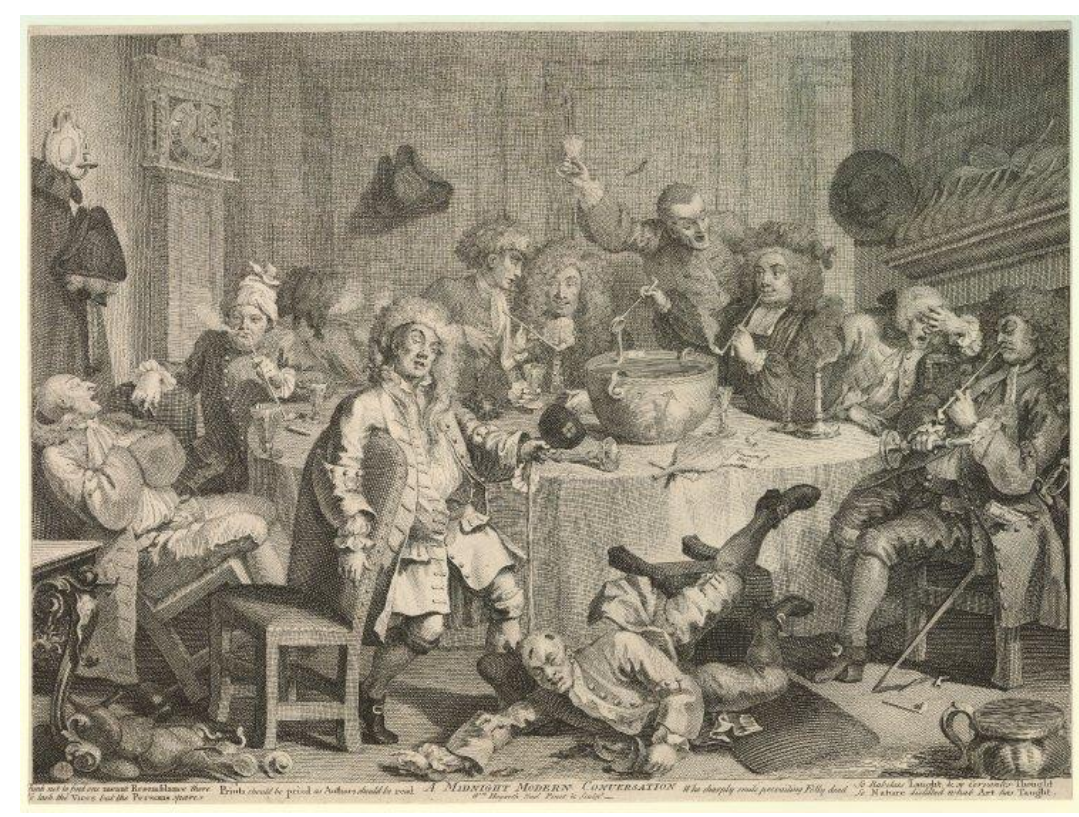

Fonte: British Museum, 1733.

Na década de 1750, Hogarth produziu uma série de imagens sobre as Eleições Gerais de 1754, em especial, que traziam de modo evidente seu propósito em responsabilizar os governantes pelo comportamento imoral da população. As Eleições Gerais eram convocadas a cada sete anos e definiam os 558 Membros do Parlamento (MP) da Inglaterra e Escócia, e era um momento em que as tensões regionais e disputas políticas se evidenciavam, pois como o governo tendia a dominar o Parlamento, eram "nas municipalidades e suas ligações com os centros que as principais batalhas políticas ocorriam, e de certo modo era nessa esfera que o caráter do estado britânico era definido" (BLACK, 2001, p. 210). De modo geral, as eleições 
eram extremamente corruptas e paternalistas, o eleitorado ${ }^{5}$ esperava presentes, favores e outras regalias em troca de seu voto, e os recursos financeiros dos candidatos ultrapassavam a ideologia como fator decisivo na escolha dos representantes.

Em 1753, Hogarth, percebendo a potencialidade da temática dentro de sua perspectiva do moderno objeto moral, anunciou uma série de imagens sobre as Eleições que ocorreriam em 1754. As quatro telas sob óleo foram produzidas entre 1754-1755, e as gravuras começaram a ser produzidas em 1754, mas apenas foram finalizadas em 1758. A polêmica e caótica eleição em Oxforshire acabou inspirando as obras, ainda que Hogarth não tenha feito qualquer menção direta ao local ou seus personagens, por simbolizar todo o caos e corrupção imanentes ao processo eleitoral britânico ditado por interesses locais. A tradicional hegemonia do Partido Tory foi desafiada pelo Duque de Malbourough, que ignorando acordos com as oligarquias locais lançou dois candidatos do Partido Whig aos assentos da cidade e do condado: Sir Edward Turner e Lorde Parker. Isso provocou uma reação em cadeia de estratégias agressivas de cooptação do eleitorado e acusações de corrupção entre os dois partidos. Os tories acusavam os whigs de corruptos e de republicanos, e os whigs os acusavam de jacobitas. Cada lado articulou a multidão ao ataque com panfletos e cartazes e tentou desmoralizar os candidatos do lado oposto, denunciando as fragilidades e hipocrisias do celebrado sistema político.

Destacamos aqui a primeira (fig.4) e a quarta tela (fig.5), pois consideramos que sintetizam bem as críticas do artista tanto ao sistema eleitoral corrupto e seus efeitos devastadores na sociedade. Apesar de sua proximidade com partidários whigs, Hogarth nunca declarou uma posição política oficial e sempre se manteve extremamente cético em relação às intenções dos homens em posição de poder. O que pode ser observado através de suas obras e também de sua biografia é um forte sentimento patriótico, aversão aos estrangeirismos e o desejo por uma sociedade ordenada de acordo com os preceitos ilustrados. Nesse sentido, ambos os partidos foram ridicularizados pelo artista, pois ambos colocavam seus interesses pessoais à frente do bem comum.

A primeira tela "Entretenimento da Eleição" (fig.4) trazia um tradicional jantar partidário às vésperas da eleição, os banquetes eram uma forma de conquistar aliados e

\footnotetext{
5 De acordo com o estatuto de 1429, era necessária uma propriedade alodial avaliada em mais de 40 shillings, mas na prática esse valor poderia ser referente à renda ou mesmo arrendamento, e em algumas regiões, era necessário o pagamento de uma taxa de auxílio aos pobres. De todo modo, o sistema se ordenava de maneira que apenas os membros mais proeminentes de cada região fossem elegíveis e apenas os mais bem sucedidos financeiramente pudessem eleger.
} 
reafirmar alianças. É possível supor que se tratava de uma reunião do Partido Whig, mas pelo retrato arranhado do rei da Revolução Gloriosa, William III, também podemos supor que os membros do Partido Tory realizaram banquetes no local anteriormente. Os "respeitosos" candidatos a magistrado buscam votos através da adulação e do suborno, e o próprio ritual eleitoral era ridicularizado como uma festa marcada pelos excessos, imoralidade e falta de compostura.

Abaixo do retrato do monarca, uma banda de música que infere o caráter festivo e barulhento do evento. Em cada canto, os dois candidatos (identificados pelas vestes azul clara) tentam agradar seu eleitorado, mas sua falsidade fica bastante explícita em seus semblantes: no canto esquerdo o candidato beija uma senhora grávida bastante a contragosto, enquanto à direita o outro força um sorriso ao mesmo tempo em que tenta se esquivar de um grupo de bêbados falando em seu ouvido. O solene jantar partidário foi representado como uma cena de taberna com muita bebida e desordem. Em todos os cantos da imagem encontramos sinais de tentativas de suborno, através das ofertas de favores e presentes. Uma das características do moderno objeto moral era o uso de elementos da pintura histórica, no caso o encontro político, para subverter a narrativa com elementos vulgares, e tecer suas críticas através do cômico e do ridículo.

Figura 4 - An Election Entertainment, William Hogarth

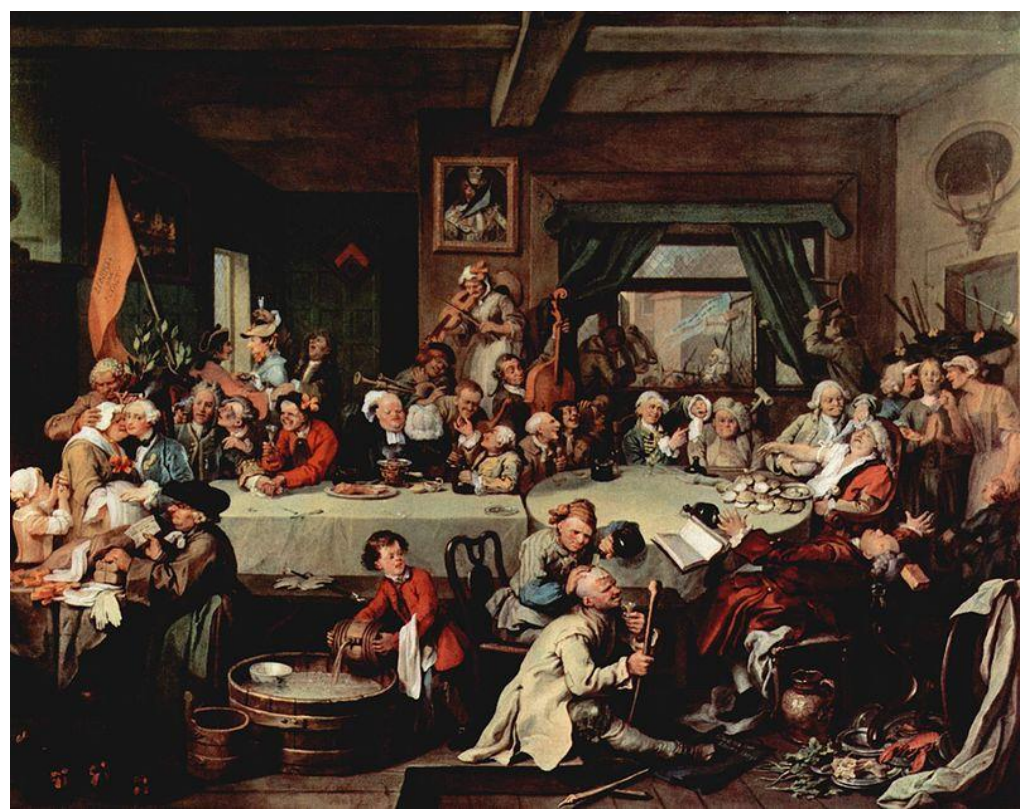

Fonte: John Soane's Museum, 1754-55. 
Seguindo essa lógica, em Chairing the Member (Instituindo ou Consagrando o Membro do Parlamento) (fig. 5) a cena é centralizada com a comemoração do triunfo de um candidato tory, sendo erguido numa cadeira, mas quase caindo pela confusão causada pela oposição insatisfeita com o resultado. Inspirado no caso acima citado de Oxfordshire, onde a eleição do candidato tory por uma pequena margem de diferença provocou contestações do resultado pelos whigs, que possuíam a maioria na Câmara dos Comuns e conseguiram que o candidato whig levasse o assento, criando um clima de grande instabilidade e questionamento da seriedade do sistema eleitoral. Mais uma vez um momento histórico se tornava objeto de escárnio justamente pela ambição desmedida de seus personagens. A violência e desordem marcam o fim do processo eleitoral, e a corrupção dos representantes reflete na própria população. No canto direito, o menino urinando em um macaco com vestes de cavalheiro, indicava o escárnio do artista com a situação como um todo. O macaco poderia simbolizar um político, pois era o símbolo da imitação e falsidade, e o ato do menino de urinar o desprezo da população com suas atitudes.

Figura 5 - Chairing the Member, William Hogarth

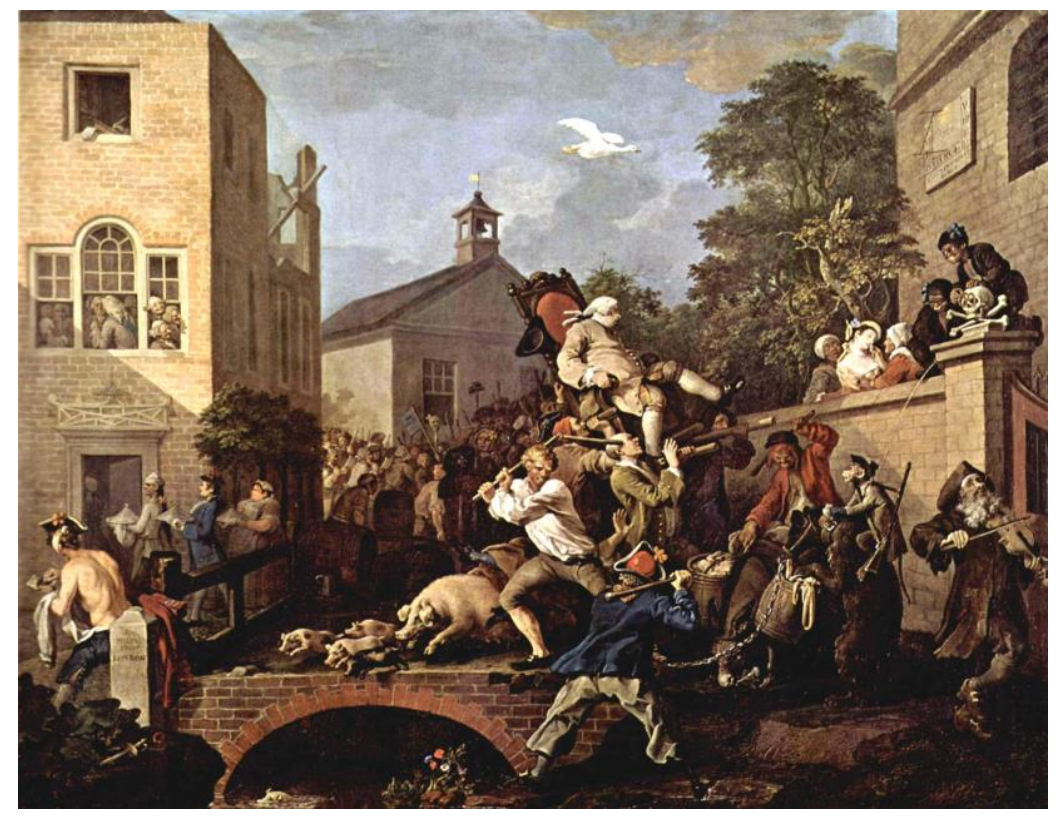

Fonte: John Soane’s Museum 1754-55.

Assim como em South Sea Scheme (fig.1), a ganância e a corrupção daqueles que deveriam zelar pela moral refletem uma sociedade corrompida. A sua crítica às autoridades corruptas não derivava de um desejo de subversão da ordem política, mas de uma proposta de moralização dos governos e também dos indivíduos, através da coerência e da 
responsabilidade social. A estética proposta por Hogarth, como explica Paulson (1997, p. xlii) era assim baseada num corpo político que não enfatizava a imposição de um monarca, como os tories e jacobitas, ou uma oligarquia, como os whigs, mas uma "variedade de partes", aristocratas e pessoas comuns, representados de acordo com sua natureza. Desse modo, Hogarth buscou produzir para um público diverso: "a todos e a ninguém”, como ele mesmo definiu em seus manuscritos, mas especialmente ao "indivíduo comum", aquele que não estava contaminado com um conhecimento pomposo e pedante sobre a arte, tão preso a regras, nomes e datas que era incapaz de apreciar a beleza em sua verdadeira forma.

\section{CONSIDERAÇÕES FINAIS}

No século das Luzes, a condição humana substituía a condição da alma como centro das discussões filosóficas, e isso se refletiu bastante na produção visual de Hogarth, que se mostrou constantemente preocupado em "estudar/satirizar" o comportamento dos indivíduos e da sociedade moderna. A representação do cotidiano e do "vulgar" já havia sido feita celebremente por artistas holandeses do século XVII como Rembrandt e Jan Steen com suas obras sobre "pessoas comuns", bêbados e mendigos, mas o século XVIII e as Luzes trariam um julgamento moral para a abordagem realista. As obras de Hogarth, como observamos, traziam o humor e a acidez da pintura holandesa seiscentista, mas também uma séria preocupação com a instrução moral de seu público, que para o artista justificava a elevação de seu objeto a um patamar acima da "sublime pintura histórica". Ainda que tratasse de temas mundanos, o artista acreditava que seu viés pedagógico dignificava sua produção e a tornava de extrema relevância para o cenário das artes na Inglaterra. Esse intuito estava em consoante diálogo com outras manifestações do período, como o romance inglês e os periódicos de comportamento como The Spectator de Joseph Addison, cada qual a seu modo, empenhados em ilustrar uma audiência mais ampla.

Hogarth abriu caminho e inspirou outros pintores e gravadores a uma leitura realista e satírica do mundo moderno, como Paul Sandby, John Collet, Thomas Rowlandson, além desses, pintores de aquarela como Thomas Girtin e J. M.W. Turner partiriam de uma perspectiva naturalista na segunda metade do século XVIII, que pode ter sido inspirada nos princípios do artista. Como destaca Gatrell, “O que estava sendo desenvolvido era uma estética metropolitana que proporcionou que as imagens registrassem, informassem, 
celebrassem, divertissem, zombassem ou comentassem, ao invés de pontuar grandiosos argumentos sobre o gosto" (GATRELL, 2014, p. 236-237).

$\mathrm{Na}$ Inglaterra pós-Revolução Gloriosa, a heterodoxia não era uma subversão do sistema, mas parte dele, no sentido de que incorporava os princípios idealizados pelos liberais whigs, ainda que na prática a intolerância, a opressão e a superstição ainda fossem recorrentes. Entre os artistas ingleses que seguiram esse caminho, Hogarth se destacou como aquele que mais combinou em sua formulação estética elementos ilustrados na primeira metade do século XVIII, como a valorização da observação da natureza, uma perspectiva racional (que abominava superstições e crenças infundadas) e uma preocupação com o papel pedagógico da arte dentro de uma composição visual que desafiava as tradições estéticas estabelecidas. Desse modo, defendemos a tese de que, mesmo dentro de um discurso moralizante, Hogarth não era um artista reacionário ou conservador puritano, mas um ilustrado dentro de um contexto de mudanças culturais, políticas e sociais que afetavam especialmente as classes médias.

\section{REFERÊNCIAS ICONOGRÁFICAS / SITES}

http://www.britishmuseum.org/research/collection_online/collection_object_details.aspx?obje ctId=1417125\&partId=1\&people=120911\&peoA=120911-2-60\&page=1. Acesso: $30 / 05 / 2018$ às $15 \mathrm{~h} 40 \mathrm{~min}$.

https://www.metmuseum.org/art/collection/search/396045. Acesso: 30/05/2018 às 15h40min. http://www.britishmuseum.org/research/collection_online/collection_object_details.aspx?obje ctId=1400432\&partId=1\&people=120911\&peoA=120911-2-60\&page=1. Acesso: $30 / 05 / 2018$ às $15 \mathrm{~h} 50 \mathrm{~min}$.

https://commons.wikimedia.org/wiki/File:William_Hogarth_028.jpg. Acesso: 30/05/2018 às $16 \mathrm{~h}$.

https://en.wikipedia.org/wiki/Humours_of_an_Election\#/media/File:William_Hogarth_029.jp g. Acesso: 30/05/2018 às 16h.

\section{REFERÊNCIAS BIBLIOGRÁFICAS}

ADDISON, J; STEELE, R. The Spectator: Volumes 1, 2 and 3. Project Gutenberg, 2004.

BAKHTIN, Mikhail. Cultura Popular na Idade Média: o contexto de François Rabelais. São Paulo: Hucitec, 2010.

BLACK, Jeremy. A subject for taste: culture in eighteenth-century England. Londres - Nova York: Hambledon and London, 2005. 
BURKE, Peter. Cultura Popular na Idade Moderna. São Paulo: Companhia das Letras: 2010.

FIELDING, Henry. Joseph Andrews. T.H. Beet Printing Co., Limited, Toronto, 1947.

GATRELL, Vic. First Bohemians. England: Penguin Books, 2014.

GOMBRICH, E. H. The Uses of Images. London, England: Phaidon, 1999.

LANGFORD, Paul. Eightennth Century Britain: a very short introduction. Oxford, New York. Oxford Press: 1984.

NERY, Laura. A Caricatura: microssomo da questão da arte na modernidade. Tese de Doutorado. Rio e Janeiro, RJ. PUC-RIO, 2006.

NICHOLS, J.B (org.). Anecdotes of William Hogarth Written by himself. England, London. J.B. Nichols and Son, Parliment Street: 1833.

PAULSON, Ronald. Satire and the Novel in Eighteenth-century England. Yale Press University, 1967.

Hogarth: Modern Moral Subject: 1697-1732/ High and Low Art: 1732-1750/ Art and Politics: 1750-1764. Rutgers University Press. 1991.

. The Beautiful, novel and strange: aesthetics of heterodoxy. Baltimore: The John Hopkins University Press, 1996.

PORTER, Roy. Enlightenment: Britain and Creation of the Modern World. London, England: Penguin Books, 2000.

UGLOW, Jenny. Hogarth: a life and a world. Londres, England. Faber and Faber, 1997. 